\title{
Determination of Heavy Metals in Fish Tissues, Water and Sediment from the Onitsha Segment of the River Niger Anambra State Nigeria
}

\author{
Izuchukwu Ujah I*, Okeke DO and Okpashi VE
}

Department of Medical Biochemistry, Efab International School, University of Nigeria, Nsukka, Nigeria

\begin{abstract}
The gills, flesh, intestines and skins of fish from Onitsha segment of River were carefully, dissected from the fish samples. Water and sediment samples were equally collected from two sites for heavy metal determination using Atomic Absorption Spectrophotometer (AAS 220 FS). The highest concentration detectable was in the sediment sample followed by the concentrations in the fish samples. Iron concentration detected was highest followed by lead with antimony and cadmium mostly undetectable. Variations in the parameters determined were found to be statistically significant at $p<0.05$.
\end{abstract}

Keywords: Bioaccumulation; Heavy metals; Fishes; River Niger; Onitsha; Anambra state

\section{Introduction}

Environmental pollution is a worldwide problem, with heavy metals pollution becoming largely prevalent [1]. Heavy metals are those metallic elements with relative atomic masses higher than iron [2]. As major pollutants they have the tendency to accumulate almost in a nonbiodegradable form in water, sediments and organisms such as fish with some toxic effects [3]. Heavy metal pollution results from progress in industries, urbanization, as well as commercial activities. Sources of environmental heavy metals include emissions from industry, waste incinerators, dumpsites, purification of metals, electronics, cosmetics and various other sources [4]. These metals find their way into water bodies either through direct disposal into water, emission into the water bodies, tidal current flood, or via water flow processes [5]. In addition to heavy metals, large amounts of organic materials are released into water bodies and may be broken down by bacterial activities resulting in reduction of oxygen level or anaerobic conditions in the variety of the effluents [6]. All over the world, rivers and sea bodies end up as receptacle for chemicals, organic and heavy metal pollutants. This is mainly because most industries and factories are located near the bank of the river (WHO/UNEP). This has resulted in several cases of pollution in aquatic environments [7,8]. Typical instances of river pollution in Nigeria have been reported: Challawa River in Kano [9], pollution of Calabar river [10], pollution in Aba river [11] and a lot of others. The concentration of heavy metals in cases of river pollution depends on annual and seasonal fluctuations. River Niger is the third largest river in the world stretching 2,610 miles $(4200 \mathrm{~km})$ from Guinea through Mali and into Nigeria [12]. It harbours about 250 species of fish [13]. River Niger serves as veritable source of large quantity of fish production for human consumption. Fish is highly valued for food and it contains a balanced level of amino acids, vitamin B12, cholesterol, high polyunsaturated fatty acids and accounts for about $40 \%$ of animal protein in the diet of Nigerians [14]. Fish have been noted for their notorious ability to concentrate heavy metals in their muscles and other part of their body [15].

Accumulated of heavy metals in organisms such as plankton can be transferred to fish, and from the fish to scavenger birds and man which are higher in the food chain [16]. This leads to a progressive increase in the concentration of a substance in the food chain (biomagnifications) more intake of liquid than its excretion from an organism (bioconcentration) [17]. Heavy metals are associated with so many health risks and the effect such as nausea, diarrhoea, cancer, effects on haemoglobin synthesis etc., the health effects depend on the heavy metal in question, the route of exposure, duration of exposure; the age of the individual exposed and the dosage during exposure.

Measurement of heavy metals in river is important because it is the route through which metals are flushed from large area of land into oceans [18]. It is also important because inside the water, these heavy metals get into other organism such as fish which is consumed by man. This measurement which will give an indication of pollution can be done using water, sediment or some organisms such as fish [19]. Earlier studies have shown that sediments have higher levels of heavy metals than the water which shows that heavy sediments act as a sink for heavy metals [20,21]. Studies carried out in Lagos lagoon revealed a higher value in the whole body of fish as well as different part than the water sample [22]. The results obtained from this study will give an indication of the level of pollution by heavy metal at the Onitsha segment of the river Niger. The Onitsha segment of the River Niger is surrounded by a lot of commercial and industrial activities. These industrial and commercial activities generate all forms of wastes including heavy metals which are readily disposed into the River Niger. In the river these heavy metals may settle in the sediment where they become available to the burrowing organisms that settle in sediments. These wastes which include heavy metals may also dissolve in the water or become bioavailable to aquatic inhabitants such as fishes. These benthic organisms such as snails and other aquatic organisms such as fish are consumed by man. The heavy metals that have accumulated in fish or other aquatic organisms, or dissolved in water thus become indirectly introduced into man either through the use of the water or the consumption of the aquatic organisms. These heavy metals have been associated with so many health problems such as cancer, neuropsychological problems, kidney problems and other numerous

*Corresponding author: Izuchukwu Ujah I, Department of Medical Biochemistry, Efab International School, University of Nigeria, Nsukka, Nigeria, Tel: +2348063607400 E-mail: ujahii812f@gmail.com

Received September 05, 2017; Accepted September 22, 2017; Published September 28, 2017

Citation: Izuchukwu Ujah I, Okeke DO, Okpashi VE (2017) Determination of Heavy Metals in Fish Tissues, Water and Sediment from the Onitsha Segment of the River Niger Anambra State Nigeria. J Environ Anal Toxicol 7: 507. doi: 10.4172/21610525.1000507

Copyright: (C 2017 Izuchukwu Ujah I, et al. This is an open-access article distributed under the terms of the Creative Commons Attribution License, which permits unrestricted use, distribution, and reproduction in any medium, provided the original author and source are credited. 
Citation: Izuchukwu Ujah I, Okeke DO, Okpashi VE (2017) Determination of Heavy Metals in Fish Tissues, Water and Sediment from the Onitsha Segment of the River Niger Anambra State Nigeria. J Environ Anal Toxicol 7: 507. doi: 10.4172/2161-0525.1000507

health problems. Thus, it is highly necessary to determine the level of these heavy metals present in the water, sediment and the aquatic organisms to ascertain the impact of the industrial, commercial, and human activities on the environment and then the possible health consequences on man.

\section{Materials and Methods}

The fish samples were collected using cast nets which were thrown by the fisher men and withdrawn by the means of line attached to its opening. The fish caught by the net were collected, washed, weighed and preserved in refrigerators for a day before analysis. The sediment and water samples were collected from marina area Onitsha with bowl and kept inside a metal free stopper bottle. The fishes were brought out and the gills, intestines, flesh and skin extracted with the aid of a knife. These extracted parts were then subjected to digestion. The fish parts (gills, intestines, flesh, and skin) or soil sediments were dried at $70^{\circ} \mathrm{C}$ for 24 hours. The dried samples were then ground in homogenizer. The crucibles and the caps were washed in $10 \% \mathrm{HNO}_{3}$ and ashed at $750^{\circ} \mathrm{C}$ for 2 hours in a muffle furnace. The dried samples were weighed into the crucibles and ash was then scraped into vials and the crucibles rinsed with $10 \mathrm{ml}$ acid with the aid of a repippetor. The vials were then capped and shaken thoroughly. The extract was diluted to $1 \mathrm{~L}$ with distilled water and the diluted extract was measured by atomic absorption spectrophotometer spectra AA model number 220FS.

\section{Discussion and Conclusion}

The concentrations of heavy metals determined in the samples are presented in Tables 1-3. Lead, copper and iron were detectable in the sediment while antimony and cadmium were not detectable. The concentration of iron is higher in the sediment than its concentration in the fish and water samples. The high content of iron in the sediment may be due to clayey material that may form the river bed. It may also be due to human activities such as the discharge of untreated sewage that contain iron as well as the ability of the sediment to act as a sink [21]. Furthermore, it has been reported that iron occurs in high concentrations in Nigerian soils. High concentrations of iron in the sediment had been reported by [22], who had carried out similar research in Lagos lagoon. In the sediment $\mathrm{Pb}$ and $\mathrm{Cu}$ were also detected while of antimony and cadmium was not detectable.

In the parts of the fish and for all fish analysed, the concentration of lead ranged from $0.313 \pm 0.093-0.539 \pm 0.235 \mathrm{mgkg}^{-1}$, while the concentration of copper ranged from $0.007 \pm 0.002-0.010 \pm 0.001 \mathrm{mgkg}$

\begin{tabular}{|c|c|c|c|c|c|}
\hline & Lead & Copper & Iron & Cadmium & Antimony \\
\hline Site 1 & $0.056 \pm 0.002$ & $0.002 \pm 0.032$ & $0.153 \pm 0.150$ & n.d \pm 0.000 & n.d \pm 0.000 \\
\hline Site 2 & $0.050 \pm 0.001$ & $0.001 \pm 0.004$ & $0.150 \pm 0.142$ & n.d \pm 0.000 & n.d \pm 0.000
\end{tabular}

Table 1: Heavy metals concentrations in water from River Niger.

\begin{tabular}{|c|c|c|c|c|c|}
\hline & Lead & Copper & Iron & Cadmium & Antimony \\
\hline Site 1 & $0.566 \pm 0.002$ & $0.003 \pm 0.007$ & $1.727 \pm 0.005$ & n.d \pm 0.000 & n.d \pm 0.000 \\
\hline
\end{tabular}

\begin{tabular}{|l|l|l|l|l|l|l|}
\hline Site 2 & $0.560 \pm 0.002$ & $0.002 \pm 0.007$ & $1.721 \pm 0.006$ & n.d \pm 0.000 & n.d \pm 0.000
\end{tabular}

Table 2: Heavy metals concentration in sediment from River Niger.

\begin{tabular}{|c|c|c|c|c|}
\hline Heavy Metals & Gills & Intestines & Skin & Flesh \\
\hline Lead & $0.471 \pm 0.322$ & $0.313 \pm 0.093$ & $0.429 \pm 0.281$ & $0.539 \pm 0.235$ \\
\hline Copper & $0.009 \pm 0.001$ & $0.010 \pm 0.001$ & $0.007 \pm 0.003$ & $0.007 \pm 0.002$ \\
\hline Iron & $0.629 \pm 0.566$ & $1.149 \pm 1.988$ & $0.193 \pm 0.078$ & $0.221 \pm 0.072$ \\
\hline Cadmium & $0.001 \pm 0.003$ & $0.000 \pm 0.001$ & $0.003 \pm 0.007$ & $0.004 \pm 0.002$ \\
\hline Antimony & $0.027 \pm 0.065$ & $0.000 \pm 0.000$ & $0.000 \pm 0.000$ & $0.130 \pm 0.142$ \\
\hline
\end{tabular}

Table 3: Heavy metals concentrations in fish samples from River Niger.
${ }^{1}$ with the concentration being more in the gills and intestines than other parts of the fish. The concentration of iron ranged from 0.221 $\pm 0.072-1.149 \pm 1.988 \mathrm{mgkg}^{-1}$ with the highest concentration in the intestines. The concentrations of cadmium ranged from $0.000 \pm 0.001$ $0.004 \pm 0.002 \mathrm{mgkg}^{-1}$ and antimony ranged from $0.000 \pm 0.000-0.130$ $\pm 0.142 \mathrm{mgkg}^{-1}$. The low concentrations of cadmium and antimony in the fish samples analysed may be due to non-discharge materials rich in cadmium and antimony into the River Niger. Most of the heavy metals surveyed were detectable in the skins of all the fishes assayed. The skin of the fish serves as point of contact/exposure and as well as the point of excretion and/or depuration. The gills and the intestines of the fish generally had higher concentrations of heavy metals compared to the flesh and skins of the fish. The gills are considered the dominant site for contaminants uptake because of their anatomical and physiological property that maximize absorption from water [23]. Furthermore, the accumulation of chemicals in fish occurs through the membrane and by ingestion, during this process; metals could be retained in the gills. The high concentrations of the heavy metals in the intestines may be due to its role as ultimate depository. High concentrations of metals in the digestive tracts of fish [24-26]. In general, metals have been shown to have affinity for certain organs of the fish. There existed difference in the concentrations of heavy metals accumulated by the various fishes. These differences may be due to the feeding habits of the fish as well as age and the size of the fish [27]. In the fish the order of decrease in concentration is $\mathrm{Fe}>\mathrm{Pb}>\mathrm{Cu}>\mathrm{Sb}>\mathrm{Cd}$. This order may be due to varying environmental sources.

Antimony and cadmium were not detectable in the water and the sediment samples, iron being highest in concentration in both the water and sample. The high concentration of iron is may be due to high environmental source. The order of decrease of concentration is as follow, $\mathrm{Fe}>\mathrm{Pb}>\mathrm{Cu}$; cadmium and antimony were not detectable. The concentrations of lead in all the fish samples exceeded the UNEP [28] limit of $0.3 \mathrm{mgkg}^{-1}$ and IAEA-407 limit of $0.12 \mathrm{mgkg}^{-1}$. In the sediment, the concentration of lead was below the ANZECC (2000) recommended level of $50 \mathrm{mgkg}^{-1}$ and [29] NOOA probable effect concentration of $128 \mathrm{mgkg}^{-1}$. In the water sample, the concentration of lead was above the WHO and EPA $[30,31]$ limit of $0.05 \mathrm{mgkg}^{-1}$. The concentration of copper in all the fish samples is below the IAEA-407 recommended level of $3.8 \mathrm{mgkg}^{-1}$. In the sediment, the concentration of copper was below the ANZECC [32] limit of $65 \mathrm{mgkg}^{-1}$ and NOOA [29] probable effect concentration of $149.0 \mathrm{mgkg}^{-1}$. In the water sample, the concentration of copper is within the WHO [30] and EPA [31] limit of $2 \mathrm{mgkg}^{-1}$ and $1.3 \mathrm{mgkg}^{-1}$ respectively. In the fish, the entire fish samples are within the IAEA-407 recommended level of $146 \mathrm{mgkg}^{-1}$ of iron. In the sediments, the concentration of iron is also below the NOOA [29] lowest effect level of $2 \%$. In the water sample, the concentration of iron was above the WHO [30] and EPA [31] limit of $0.01 \mathrm{mgkg}^{-1}$ and $0.3 \mathrm{mgkg}^{-1}$ respectively. Cadmium and antimony were within the recommended levels in all the samples as they were not detectable. Thus, the concentrations of the all the heavy metals in the fish samples except lead were within the tolerable levels in the samples. Lead has been associated with many health effects in man including cancer; therefore, its concentration above the recommended level poses a danger to the aquatic organisms as well humans. Also since there are cumulative effects of these heavy metals, their concentration may rise to a level which will become toxic both to the aquatic organisms and man with unabated generation and disposal of heavy metal-containing wastes into the River Niger Onitsha segment. Thus, there is the need for regular and consistent evaluation of the heavy metal concentration of River Niger over time. 
Citation: Izuchukwu Ujah I, Okeke DO, Okpashi VE (2017) Determination of Heavy Metals in Fish Tissues, Water and Sediment from the Onitsha Segment of the River Niger Anambra State Nigeria. J Environ Anal Toxicol 7: 507. doi: 10.4172/2161-0525.1000507

\section{Conclusions}

The study revealed the contamination/pollution of River Niger, its sediment and fish by the heavy metals surveyed. These contaminations could be attributed to the industrial and commercial activities which generates wastes including heavy metals which are readily disposed into the Onitsha segment of the River Niger. Furthermore, the results also showed the accumulation of heavy metals in certain tissues of the fishes especially the gills and intestines.

\section{References}

1. Diagomanolin V, Farhang M, Jafarzadeh N (2004) Heavy Metals in the Karoon Waterway River, Iran. Toxicol Lett 15: 63-68.

2. Duffus JH (2002) Heavy Metals - A Meaningless Term. J Interna Chem 23: 793-807.

3. Storelli MM, Storelli A, Dddabbo R, Marano C, Bruno R, et al. (2005) Trace Elements in Loggerhead Turtles (Caretta caretta) from the Eastern Mediterranean Sea: Overview and evaluation. Environ Pollut 135: 163-170.

4. Hutton M, Simon C (1986) The Quantities of Cadmium, Lead, Mercury, and Arsenic Entering the UK Environment from Human Activities. Sci Total Environ 57: $129-150$.

5. Stephen B (1984) Flood Effects on Transport of Heavy Metals. International Journal Governmental Studies 122: 225-230.

6. Smith VH, Tilman GD, Nekola JC (1999) Eutrophication impacts of excess nutrient inputs on freshwater, marine, and terrestrial ecosystems. Environ Pollut 100: 179-196.

7. Velez D, Montoro R (1998) Arsenic Speciation in Manufactured Seafood Products. A Review J Food Protect 61: 1240-1245.

8. Conacher HB, Ruge BD, Ryand JJ (1993) Industrial Chemical Contamination of Foods. Food Addit Contam 10: 129-143.

9. Dana'azumi S, Bichi MH (2010) Industrial Pollution and Heavy Metal Profiles of Chalawa River. Kano Journal of Applied Sciences in Environmental Issues 5: $23-29$

10. Abu GO, Egeonu C (2008) The Current Pollution Status of New Calabar River in the Niger Delta Region of Southern Nigeria: A Profile of Antibiogram Profile of its Bacterial Isolates. African Journal of Environmental Science and Technology 2: 134-141.

11. Laws EA (1981) Determination and Assessment of Heavy Metal Content of Fish and Water from Aba River. African Journal of Biotechnology 4: 266-272.

12. Gleich PH (2000) The World's Water 2000-2001: The Biennial Reports on Fresh Water. Island Press, pp: 1-33.

13. Kusterer JM (2007) River Niger after Rainy season. Atmospheric Science Data

14. Atta MB, Els-sebule LA, Naoman MA, Kassus H (1997) Determination of Heavy Metals in Tissues of Fish. Food Chemistry 58: 1-4.
15. Sures B (2003) Parasitology Cambridge Journal 126: 553-560.

16. Farkas A, Salanki J, Speczier A (2002) Relationship Between Growth and Heavy Metal Concentration in the Organs of Bream Abramis Brama Population in Lake Balatos. Arch Environ Contam Toxicol 43: 236-243.

17. Croteau MN, Luoma SN, Stewart AR (2005) Trophic Transfer of Metals along Freshwater Food Webs: Evidence of Cadmium Biomagnification in Nature. Limnol Oceanogr 50: 1511-1519.

18. Beyhan C, Surkan Y, YucelBG, SerdalK (2010) Investigation of Histocompatiblity and Cytogenetic Effects of Heavy Metal Pollution on. Cyprinus Carpio. Medwell Journal 9: 798-808.

19. Camusso M, Vigano L, Baitstrini R (1995) Bioaccumulation of Trace Metals in Rainbow Trout. Ecotox Environ Safe 31: 133-141.

20. Benedict CO, Okoye OA, Afolabi EA (1991) Heavy Metals in Sediments. Int J Environ Study 37: 35-41.

21. Kakulu S, Osibaanjo O (1998) Heavy Metals in Sediments and Water. Nigerian J Chemical Society 13: 9-11.

22. Adeniyi AA, Yusuf KA (2007) Determination of Heavy Metals in Fish. Tissues Environ Monitor Assess 37: 451-458.

23. Hayton WL, Baron MG (1990) Rate Limiting Barriers to Xenobotic uptake by Fish Gill. Environ Contam Toxicol 15: 208-216.

24. Al-Mohanna MM (1994) Residues of Some Heavy Metals in Fishes Collected from (Red SeaCoast) Jisan, Saudi Arabia. J Environ Biol 15: 149-157.

25. Kock G, Triendl M, Hofer R (1998) Lead (Pb) in Arctic char (Salvelinus alpinus) from Oligotrophic Alpine Lakes: Gills versus Digestive Tract. Water Air Soil Pollut 102: 303-312.

26. Giguère A, Campbell PG, Hare L, McDonald DG, Rasmussen JB (2004) Influence of lake chemistry and fish age on cadmium, copper, and zinc concentrations in various organs of indigenous yellow perch (Perca flavescens). Canadian Journal of Fisheries and Aquatic Sciences 61: 1702-1716.

27. Canli M, Atli G (2003) The relationships between heavy metal (Cd, Cr, Cu, Fe $\mathrm{Pb}, \mathrm{Zn}$ ) levels and the size of six Mediterranean fish species. Environmental Pollution 121: 129-136.

28. UNEP United Nations Environmental protection Agency (1985) Reference Method for Marine Pollution Studies Determination of Total $\mathrm{Hg}$ in Marine Sediments and Suspended Solids by cold vapour. AAS, pp: 1- 26.

29. NOAA National Oceanic and Atmospheric Admistration (2009) SQUIRT, Screening Quit Reference Table for Sediments. pp: 12-15.

30. World Health Organisation (1993) Guidelines for Drinking Water Quality Recommendations. Geneva, pp: 1-5.

31. EPA (Environmental Protection Agency) (2002) Risk assessment: Technical background information. RBG Table, p: 1.

32. ANZECC (2000) (Australian and New Zealand Environment and Conservation Council, 2000) and ARMCANZ (Agriculture and Resource Management Council of Australia and New Zealand). Australian and New Zealand Guidelines for Fresh and Marine Water Quality, pp: 3-8. 